\title{
PENGARUH HIDROLISIS ENZIMATIS TERHADAP PRODUKSI BIOETANOL DARI UMBI TALAS (Colocasia gigantea Hook F)
}

\author{
Marniati Salim, Elida Mardiah, dan Febby Febrizal \\ Laboratorium Bioteknologi, Jurusan Kimia, FMIPA, Universitas Andalas \\ Email : bundosalim@gmail.com, 08126629050
}

\begin{abstract}
Umbi talas (Colocasia gigantea Hook F) are rich of starch (77.9\%), that could be fermentated to form bioethanol for reneweable energy. The ethanol were produced by fermenting the hydrolised enzymaticly by $\alpha$-amylase and glucoamylase at the variation $4,5,6,7$, and $8 \mathrm{~mL}$ for $1,2,3,4$, and 5 hours. The glucose produced was measured by Somogy-Nelson methode. The product of hydrolysed were optimum with $6 \mathrm{~mL} \alpha$-amylase and $7 \mathrm{~mL}$ glucoamylase for 4 hours wich gave $64,222 \mathrm{~g} / \mathrm{L}$ of reducing sugar. The product of ethanol were analyzed by Gas Chromatography (GC). The maximum bioethanol production obtained after 5 days fermentation was $4.0123 \%$.
\end{abstract}

Keywords : Bioethanol, umbi talas, enzymatic hydrolysed, a-amylase, glucoamylase

\section{PENDAHULUAN}

Kebutuhan Bahan Bakar Minyak (BBM) di berbagai negara akhir-akhir ini mengalami peningkatan tajam. Demikian juga konsumsi BBM di Indonesia dari tahun 2006 sampai 2011 meningkat masing-masing untuk premium dari 16,81 juta kilo liter (jkl) menjadi $25,49 \mathrm{jkl}$, sedangkan untuk solar dari $10,67 \mathrm{jkl}$ menjadi 14,49 jkl. Subsidi BBM meningkat lebih dari $100 \%$ yaitu 64,212 triliyun rupiah menjadi 137,379 triliyun rupiah ${ }^{[1]}$.

Untuk mengantisipasi krisis BBM pada masa yang akan datang, telah berkembang saat ini pemanfaatan etanol sebagai bahan bakar alternatif yaitu pembuatan bioetanol untuk gasohol (campuran gasolin dan alkohol). Jadi bioetanol dapat digunakan dalam sektor transportasi setelah dicampurkan dengan gasoline. Dalam pemanfaatannya sebagai bahan bakar kendaraan dapat digunakan dengan perbandingan $10 \%$ bioetanol absolut dan $90 \%$ bensin. Campuran dari larutan ini biasa disebut dengan gasohol E-10. Keuntungan penggunaan bioetanol dalam sektor transportasi dapat menurunkan kualitas udara dengan memiliki tekanan uap rendah, daya mudah terbakar yang rendah pada kendaraan, dan mengurangi pembebasan emisi
$\mathrm{CO}$ dan $\mathrm{SO}_{2}$ sehingga mengurangi efek rumah $\mathrm{kaca}^{[2-4]}$.

Bioetanol dapat dihasilkan melalui proses fermentasi glukosa dari penguraian sumber karbohidrat dengan bantuan mikroorganisme sebagai bahan baku. Sumber karbohidrat dapat digunakan umbi talas (Colocasia gigantea Hook $F$ ) yang termasuk tanaman umbi-umbian dengan kandungan pati yang cukup tinggi $77,9 \%{ }^{[5]}$, maka peneliti mencoba melakukan penelitian untuk menghasilkan bioetanol dengan mengamati variabel-variabel yaitu pengaruh variasi penambahan enzim $\alpha$-amilase dan glukoamilase serta lama hidrolisisnya, terhadap gula reduksi yang dihasilkan dan juga mengamati lama fermentasi terhadap konsentrasi etanol dan konsentrasi glukosa sisa.

\section{METODOLOGI PENELITIAN}

\section{Alat dan Bahan}

Alat yang digunakan adalah neraca analitik, alat-alat gelas, inkubator, autoklaf, hot plate stirrer, termometer, spektrofotometer (Thermo Spectronic Genesys 20), jarum ose, sentrifus, shaker, $\mathrm{pH}$ indikator, seperangkat peralatan 
destilasi, stopwatch, dan peralatan GC (QP 2010 S SHIMADZHU).

Bahan yang digunakan adalah umbi talas (Colocasia gigantea Hook F), natrium karbonat (Merck), kalium natrium tartarat (Merck), natrium bikarbonat, natrium sulfat (Merck), tembaga sulfat hidrat (Merck), asam sulfat pekat, natrium tungstat (Merck), asam molibdat, natrium hidroksida, akuabides, asam pospat85 \%, enzim $\alpha$-amilase dan glukoamilase (Novozyme), asam asetat, natrium asetat, medium Potato Dextrose Agar (PDA), $\left(\mathrm{NH}_{4}\right)_{2} \mathrm{PO}_{4}, \mathrm{MgSO}_{4} .7 \mathrm{H}_{2} \mathrm{O}, \mathrm{KH}_{2} \mathrm{PO}_{4}$, yeast extract dan etanol $96 \%$.

Semua alat dengan medium yang digunakan disterilisasi autoklaf pada suhu $121{ }^{\circ} \mathrm{C}$ selama 15 menit. Pada penelitian ini dilakukan beberapa tahap perlakuan yaitu mengamati:

1. Proses hidrolisis, variasi penambahan $\alpha$ amilase dan glukoamilase terhadap konsentrasi gula reduksi.

2. Penentuan konsentrasi gula reduksi dengan metode Somogy-Nelson.

3. Penentuan pengaruh variasi lama fermentasi terhadap konsentrasi etanol dengan Gas Chromatography (GC).

4. Penentuan konsentrasi glukosa sisa pada variasi lama fermentasi.

\section{Prosedur Kerja}

\section{Persiapan sampel}

Sampel yang digunakan dalam penelitian ini adalah tepung talas yang dibuat dari umbi talas (Colocasia gigantea Hook F). Umbi talas dikupas dan dicuci, setelah bersih dihaluskan menggunakan penggiling. Umbi yang telah halus dikeringkan \pm 3 hari dengan bantuan sinar matahari hingga menjadi tepung. Tepung diayak menggunakan ayakan dengan pori 425 $\mu \mathrm{m}$, untuk menyeragamkan ukuran partikel dan disimpan di tempat yang kering. Tepung siap digunakan sebagai sampel dalam jangka waktu yang lama.

\section{Proses hidrolisispenentuan pengaruh variasi penambahan $\alpha$-amilase terhadap konsentrasi gula reduksi}

Tepung umbi talas $15 \mathrm{~g}$ ditambah dengan 100 $\mathrm{mL}$ akuabides dalam erlenmeyer $250 \mathrm{~mL}$. $\alpha$ - amilase ditambahkan dengan variasi 4, 5, 6, 7 dan $8 \mathrm{~mL}$ dan dipanaskan pada suhu $80{ }^{\circ} \mathrm{C}$, diaduk $250 \mathrm{rpm}$ selama 2 jam. Selanjutnya dilakukan pengingaktifan enzim dengan cara dipanaskan pada suhu $\pm 105^{\circ} \mathrm{C}$ selama 15 menit. Larutan disentrifus, filtratnya diambil dianalisis dengan metode Somogy-Nelson. Sampel yang memiliki absorban paling tinggi dilanjutkan untuk proses hidrolisis dengan menggunakan enzim glukoamilase. Didapatkan kondisi optimum dari variasi penambahan $\alpha$ amilase $^{[7]}$.

\section{Penentuan pengaruh variasi penambahan glukoamilase dan lama hidrolisis terhadap konsentrasi gula reduksi}

Tepung umbi talas $15 \mathrm{~g}$ ditambah $100 \mathrm{~mL}$ aquabides dalam erlenmeyer $250 \mathrm{~mL}$, ditambahkan $\alpha$-amilase $6 \mathrm{~mL}$, dipanaskan pada suhu $80{ }^{\circ} \mathrm{C}$, dan diaduk $250 \mathrm{rpm}$ selama 2 jam. Selanjutnya dilakukan hidrolisis menggunakan enzim glukoamilase $4,5,6,7$, dan $8 \mathrm{~mL}$, diatur pH 5 dengan penambahan asam asetat dan pHnya dipertahankan dengan buffer asetat. Larutan diaduk $250 \mathrm{rpm}$ selama 1, 2, 3, 4, dan 5 jam pada $\mathrm{T}=55{ }^{\circ} \mathrm{C}$. Setelah itu dilakukan penginaktifan enzim dan larutan disentrifus, filtratnya diambil dan konsentrasi gula reduksinya dianalisis dengan metode SomogyNelson. Sampel yang memiliki konsentrasi gula reduksi paling tinggi dilanjutkan untuk proses fermentasi. Didapatkan kondisi optimum dari variasi penambahan glukoamilase dan lama hidrolisis ${ }^{[7]}$.

\section{Penentuan konsentrasi gula reduksi sampel dengan metode Somogy-Nelson}

Hidrolisat yang telah diinaktifkan enzimnya, disentrifus, $1 \mathrm{~mL}$ filtrat dipipet dan diencerkan dalam labu ukur $10 \mathrm{~mL}$ (pengenceran $10^{-1}$ ), kemudian diambil $1 \mathrm{~mL}$ dari pengenceran $10^{-1}$ dimasukan ke dalam labu ukur $10 \mathrm{~mL}$ dan diencerkan kembali (pengenceran $10^{-2}$ ), demikian selanjutnya sampai pengenceran $10^{-4}$. Kemudian $1 \mathrm{~mL}$ dari pengenceran $10^{-4}$ ditambahkan dengan $1 \mathrm{~mL}$ reagen Nelson di dalam tabung reaksi, lalu dipanaskan pada air mendidih selama 20 menit. Setelah didinginkan tabung reaksi hingga suhu larutan $\pm 25^{\circ} \mathrm{C}$, lalu ditambahkan $1 \mathrm{~mL}$ reagen fosfomolibdat dan $7 \mathrm{~mL}$ akuades. Larutan dikocok, lalu didiamkan selama 30 menit, 
kemudian absorban masing-masing larutan sampel diukur pada panjang gelombang 580 $\mathrm{nm}$ dengan spektrofotometer. Konsentrasi gula reduksi didapatkan dengan memasukkan nilai absorban pada persamaan regresi kurva kalibrasi standar.

\section{Fermentasi bioetanol}

\section{Penentuan pengaruh variasi lama fermentasi terhadap konsentrasi etanol}

Sebanyak $50 \mathrm{~mL}$ hidrolisat dimasukkan ke dalam $100 \mathrm{~mL}$ medium nutrisi, diatur pHnya menjadi 5, ditambahkan $20 \mathrm{~mL}$ Saccharomyces cerevisiae, ditutup dengan alumunium voil. Kemudian sampel dishaker pada kecepatan $200 \mathrm{rpm}$ selama 3, 4, 5, 6, dan 7 hari. Proses fermentasi etanol dilakukan secara anaerob. Hasil fermentasi selanjutnya didestilasi untuk memisahkan etanol dari larutan lainnya, sampai didapatkan destilat yang diindikasikan sebagai etanol. Destilat diukur konsentrasi etanolnya dengan menggunakan GC dengan kondisi operasional: gas pembawa Helium, tekanan $52,3 \mathrm{kPa}$, kolom yang digunakan Rtx 5 MS dengan panjang kolom $30 \mathrm{~m}$ dan diameter dalam $0,25 \mu \mathrm{m}$, suhu oven $60{ }^{\circ} \mathrm{C}$, suhu injeksi $150{ }^{\circ} \mathrm{C}$, volume injeksi $0,5 \mu \mathrm{L}$, total alir 0,94 $\mathrm{mL} / \mathrm{min}$ dan detektor FID serta konsentrasi glukosa sisa fermentasi juga diukur dengan spektrofotometer.

Penentuan konsentrasi glukosa sisa pada variasi lama fermentasi

Hasil fermentasi yang telah diinaktifkan enzimnya, disentrifus, $1 \mathrm{~mL}$ filtrat diencerkan dalam labu ukur $10 \mathrm{~mL}$ (pengenceran $10^{1}$ ). 1 $\mathrm{mL}$ larutan dari pengenceran $10^{1}$ dimasukan ke dalam labu ukur $10 \mathrm{~mL}$ dan diencerkan kembali (pengenceran $10^{2}$ ). Kemudian $1 \mathrm{~mL}$ dari pengenceran $10^{2}$ ditambahkan dengan 1 $\mathrm{mL}$ reagen Nelson di dalam tabung reaksi, lalu dipanaskan pada air mendidih selama 20 menit. Setelah itu didinginkan tabung reaksi hingga suhu larutan $\pm 25^{\circ} \mathrm{C}$, lalu ditambahkan $1 \mathrm{~mL}$ reagen fosfomolibdat dan $7 \mathrm{~mL}$ akuades. Larutan dikocok lalu didiamkan selama 30 menit, kemudian absorban masing-masing larutan sampel diukur pada panjang gelombang $580 \mathrm{~nm}$ dengan spektrofotometer. Konsentrasi gula reduksi didapatkan dengan memasukkan nilai absorban pada persamaan regresi kurva kalibrasi standar.

\section{HASIL DAN DISKUSI}

Pengaruh variasi penambahan $\alpha$-amilase terhadap konsentrasi gula reduksi

Pengaruh variasi penambahan $\alpha$-amilase terhdap konsentrasi gula reduksi pada proses hidrolisis umbi talas (Colocasiagigantea Hook $F$ ) dapat dilihat pada Gambar 1. Pada Gambar 1 , dapat dilihat bahwa variasi penambahan $\alpha$ amilase yang dilakukan berpengaruh terhadap konsentrasi gula reduksi. Konsentrasi akan meningkat seiring dengan peningkatan variasi penambahan $\alpha$-amilase $(4-6 \mathrm{~mL}$ ). Hal itu terjadi karena jumlah enzim belum cukup untuk menghidrolisis substrat pati. Akan tetapi setelah mencapai titik optimum tidak ada lagi peningkatan konsentrasi karena sudah terjadi kesetimbangan reaksi antara substrat dengan enzim. Konsentrasi maksimum diperoleh pada variasi penambahan $\alpha$-amilase $6 \mathrm{~mL}$ sebesar $14,222 \mathrm{~g} / \mathrm{L} . \alpha$-amilase pada proses hidrolisis akan membantu pemecahan pati menjadi maltosa.

\section{Pengaruh variasi penambahan glukoamilase dan lama hidrolisis terhadap konsentrasi gula reduksi}

Variasi penambahan glukoamilase dilakukan setelah proses hidrolisis dengan $\alpha$-amilase $6 \mathrm{ml}$ selama 2 jam. Proses hidrolisis menggunakan glukoamilase dilakukan selama 1- 5 jam.

Pada Tabel 1, terlihat bahwa variasi penambahan glukoamilase dan lama hidrolisis mempengaruhi konsentrasi gula reduksi yang dihasilkan. Pada awalnya konsentrasi meningkat seiring dengan penambahan glukoamilase (4 - $7 \mathrm{~mL})$, sedangkan pada penambahan $8 \mathrm{~mL}$ tidak terjadi kenaikan lagi karena sudah terjadi kesetimbangan reaksi.

Pengukuran konsentrasi diketahui mening-kat secara drastis setelah 4 jam. Hal tersebut diindikasikan bahwa pada hidrolisis selama 4 jam dan dibantu dengan penambahan glukoamilase, pemecahan maltosa menjadi dua gugus glukosa telah sempurna. Pada keadaan ini, dapat dilihat kondisi optimum 
terbentukanya gula reduksi. Hidrolisis pada 1 4 jam terjadi peningkatan konsentrasi. Sedangkan pada hidrolisis 5 jam terjadi penurunan konsentrasi, karena kestabilan enzim mulai menurun pada waktu inkubasi yang terlalu lama.

Pada Tabel 2, terlihat bahwa pada penambahan glukoamilase 4-7 mL terjadi peningkatan konsentrasi gula reduksi yang dihasilkan. Hal tersebut sebanding dengan kenaikan absorbannya. Pada penambahan $8 \mathrm{~mL}$ tidak terjadi lagi kenaikan konsentrasi. Konsentrasi gula reduksi tertinggi didapatkan pada penambahan glukoamilase sebanyak $7 \mathrm{~mL}$ sebesar 64,222 g/L. Pada penambahan glukoamilase $7 \mathrm{~mL}$ komposisinya tepat untuk membantu proses pemecahan maltosa menjadi dua gugus glukosa.

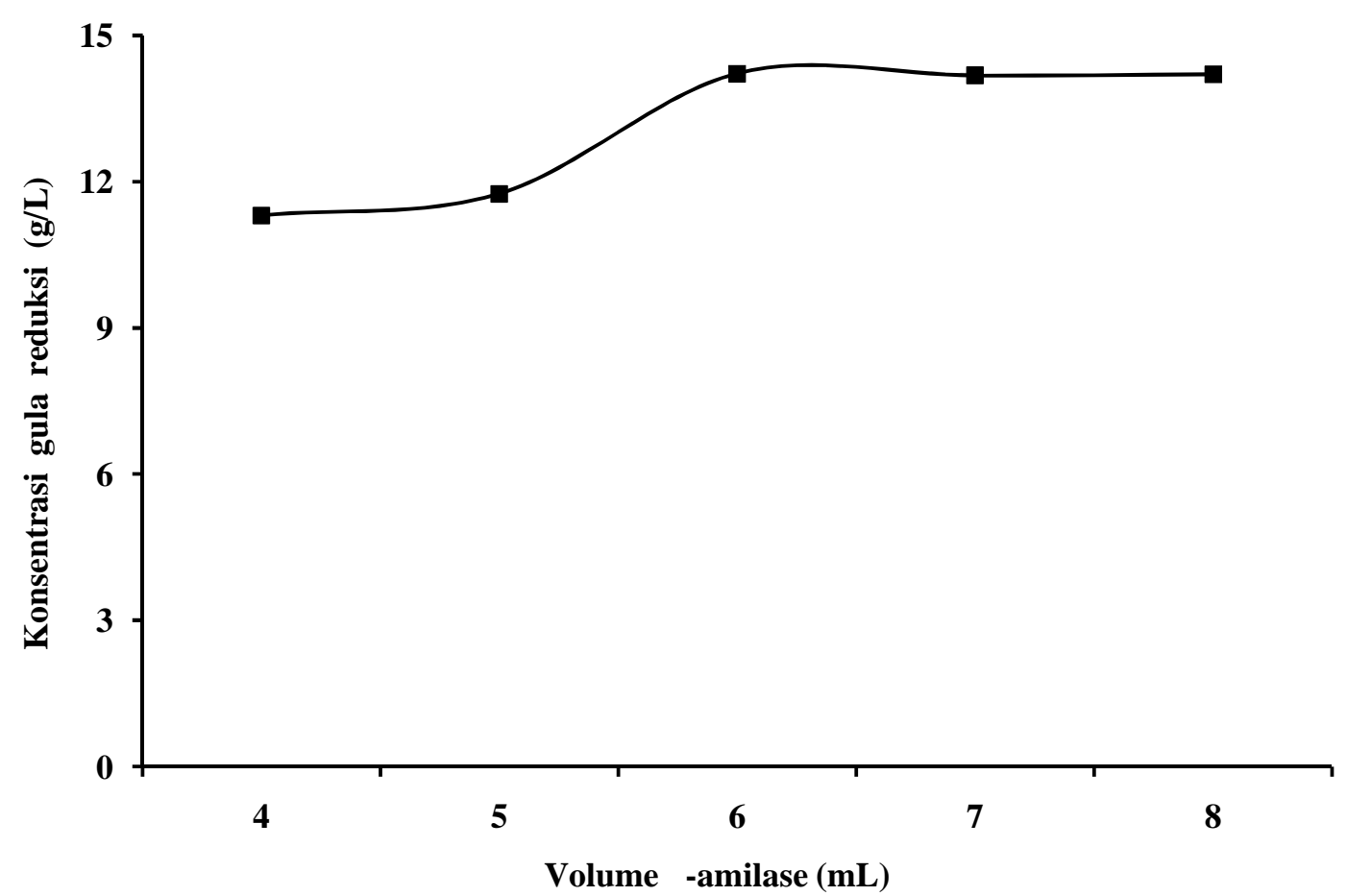

Gambar 1. Kurva konsentrasi gula reduksi yang dihasilkan dengan variasi penambahan $\alpha$-amilase

Tabel 1. Data konsentrasi gula reduksi pada variasi penambahan glukoamilase dan lama hidrolisis

\begin{tabular}{cccccc}
\hline \multirow{2}{*}{$\begin{array}{c}\text { Penambahan Glukoamilase } \\
(\mathbf{m L})\end{array}$} & $\mathbf{1}$ & $\mathbf{2}$ & $\mathbf{3}$ & $\mathbf{4}$ & $\mathbf{5}$ \\
\cline { 2 - 6 } & \multicolumn{5}{c}{ Konsentrasi gula reduksi $(\mathrm{g} / \mathbf{L})$} \\
\hline 4 & 9,955 & 10,977 & 20,088 & 41,333 & 17,977 \\
5 & 12,444 & 12,444 & 28,444 & 42,666 & 28,444 \\
6 & 13,488 & 15,955 & 34,666 & 44,444 & 32,222 \\
7 & 11,288 & 19,866 & 45,555 & $\mathbf{6 4 , 2 2 2}$ & 41,777 \\
8 & 12,666 & 19,466 & 45,333 & 64 & 40,666 \\
\hline
\end{tabular}


Tabel 2. Data konsentrasi gula reduksi setelah dihidrolisis dengan glukoamilase selama 4 jam

\begin{tabular}{ccc}
\hline Penambahan Glukoamilase $(\mathbf{m L})$ & Absorban & Konsentrasi Gula Reduksi $(\mathbf{g} / \mathbf{L})$ \\
\hline 4 & 0,158 & 41,333 \\
5 & 0,164 & 42,666 \\
6 & 0,172 & 44,444 \\
7 & 0,261 & 64,222 \\
8 & 0,26 & 64 \\
\hline
\end{tabular}

Untuk menghasilkan konsentrasi gula reduksi yang tinggi, pengaturan $\mathrm{pH}$ dan suhu hidrolisis juga harus diperhatikan. $\mathrm{pH}$ sangat berpengaruh karena dapat meningkatkan kerja enzim dan pengaturan suhu dapat mempercepat proses hidrolisis. Pada penelitian ini digunakan $\mathrm{pH} 5$ dan suhu hidrolisis $55^{\circ} \mathrm{C}$.

\section{Pengaruh variasi lama fermentasi terhadap konsentrasi etanol}

Konsentrasi etanol yang dihasilkan untuk variasi lama fermentasi dapat dilihat pada Gambar 2.

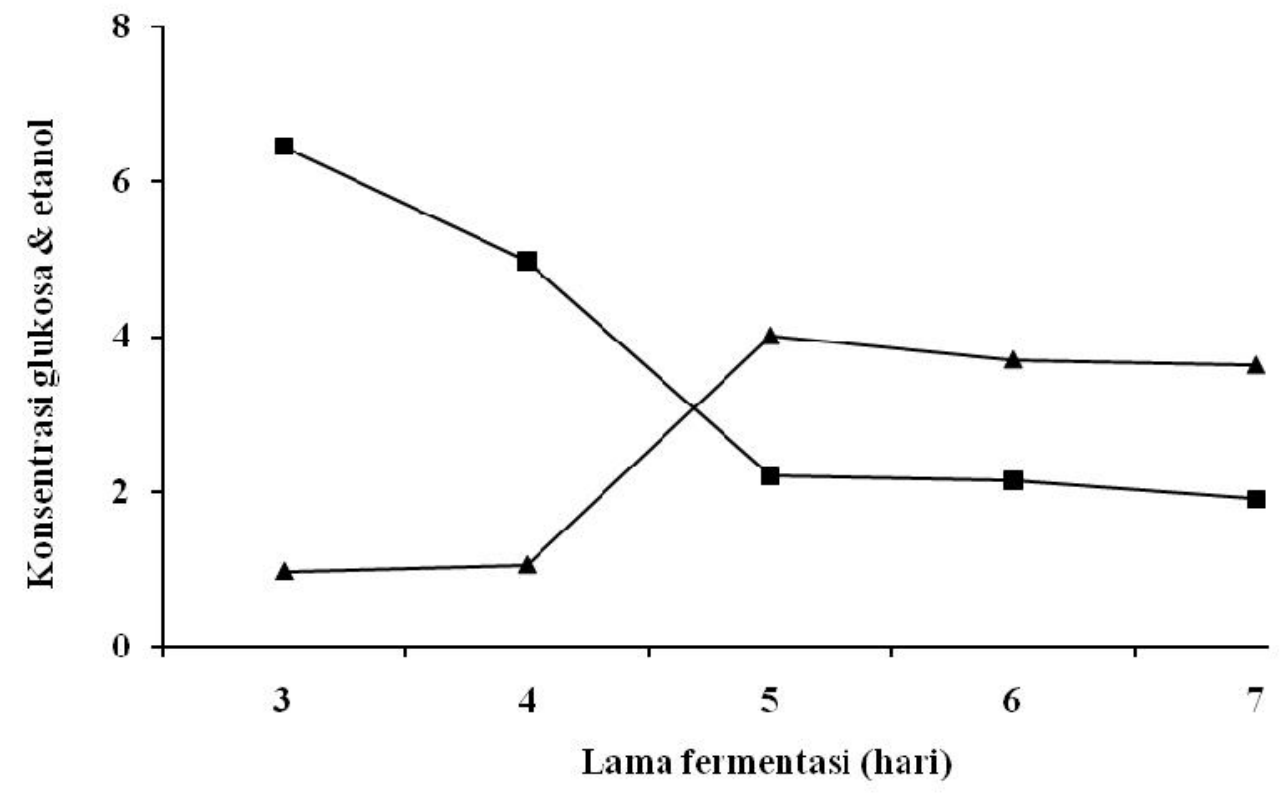

$\rightarrow$-konsentrasi glukosa (g/L) - $\longrightarrow$ konsentrasi etanol (\%)

Gambar 2. Kurva konsentrasi etanol yang dihasilkan serta konsentrasi glukosa sisa fermentasi terhadap variasi lama fermentasi

Pada Gambar 2, terlihat bahwa semakin lama waktu fermentasi, maka konsentrasi etanol yang dihasilkan juga semakin meningkat mulai dari 3 - 5 hari. Hal tersebut terjadi karena semakin lama waktu maka semakin banyak glukosa yang dapat dikonversi menjadi etanol oleh S.cerevisiae. Akan tetapi, pada 6 - 7 hari terjadi penurunan konsentrasi etanol yang dihasilkan. Hal ini disebabkan karena proses fermentasi aerob fakultatif ini memungkinkan tumbuhnya Acetobacter aceti. Bakteri ini dapat mengkonversi alkohol yang terbentuk menjadi asetat yang ditandai aroma asam pada sampel sehingga menurunkan konsentrasi etanol.

Reaksinya sebagai berikut:

$\mathrm{C}_{2} \mathrm{H}_{5} \mathrm{OH}_{(\mathrm{l})}+\mathrm{O}_{2(\mathrm{~g})} \rightarrow \mathrm{CH}_{3} \mathrm{COOH}_{(\mathrm{l})}+\mathrm{H}_{2} \mathrm{O}$

Konsentrasi etanol tertinggi dihasilkan pada fermentasi selama 5 hari sebesar $4,0123 \%$. Ini 
merupakan kondisi optimum dari pembentukan etanol, dilihat juga dari konsentrasi glukosa sisa fermentasinya.

Dari Gambar 2 dapat dilihat, semakin lama waktu fermentasi, jumlah pengurangan glukosa juga semakin besar, terlihat penurunan yang tajam konsentrasi glukosa pada 3 - 5 hari fermentasi karena pada keadaan tersebut glukosa digunakan untuk membentuk etanol dan untuk pertumbuhan S.cerevisie. Sedangkan pada 5 - 7 hari terjadi sedikit penurunan karena glukosa hanya dipergunakan sebagai sumber energy S.cerevisie dalam kelangsungan hidupnya. Konsentrasi glukosa pada 5 hari $0,220 \mathrm{~g} / \mathrm{L}$.

Konsentrasi etanol optimum yang didapatkan sebesar 4,0123\% belum sesuai dengan apa yang diharapkan, karena hasilnya jauh di bawah kadar etanol yang diproduksi dari umbi talas jenis lainnya yang mencapai $53 \%{ }^{[6]}$. Hal tersebut terjadi karena metode yang digunakan dan pemisahannya kurang maksimal. Metode fermentasi yang digunakan adalah metode batch, dimana proses fermentasi terjadi di dalam suatu tempat dan produk yang terbentuk tetap bercampur dengan substratnya. Produk yang terbentuk adalah gas $\mathrm{CO}_{2}$ dan etanol, jika produk ini tidak dikeluarkan akan meracuni S.cerevisiae. Produk yang terbentuk seharusnya dialirkan ke tempat penampungan produk, seperti pada fermentasi dengan metode kontinu. Pemisahan etanol yang terbentuk hanya dilakukan dengan cara destilasi saja, seharusnya juga dilakukan absorbansi dengan absorben $\mathrm{CaO}$, untuk menyerap $\mathrm{H}_{2} \mathrm{O}$ untuk meningkatkan konsentrasi etanol yang dihasilkan.

\section{KESIMPULAN}

Dari penelitian yang telah dilakukan dapat disimpulkan umbi Talas (Colocasia-gigantea Hook F) dapat dijadikan sebagai bahan pembuat bioetanol. Setelah dilakukan hidrolisis, hidrolisat mengan-dung glukosa 64,222 g/L. Proses hidrolisis yang memberikan hasil glukosa maksimum adalah dengan menggunakan $\alpha$-amilase $6 \mathrm{~mL}$, glukoamilase 7 $\mathrm{mL}$ dan lama hidrolisis dengan glukoamilase 4 jam. Produksi etanol maksimum terjadi pada lama fermentasi 5 hari, konsentrasi etanol yang diperoleh sebesar 4,0123\%. Produksi etanol selama fermentasi berbanding terbalik dengan konsentrasi glukosa sisa fermentasi.

\section{DAFTAR PUSTAKA}

1. www.kompas.com, Senin 12 Maret 2012, Transportasi massal perlu mendapat prioritas (Konsumsi BBM Indonesia), 11, 2012.

2. Indyah Nurdyastuti, Teknologi proses produksi bioetanol. BPPT prospek pengembangan bio-fuel sebagai substitusi bahan bakar minyak (BBM) http://www.oocities.org/markal_bppt/publis h/biofbbm/biindy.pdf, 75-83. 14 Juni 2011.

3. S. Yunoki and M. Saito. A Simple method to determine bioethanol content in gasoline using two-step extraction and liquid scintillation counting. bioresource technology, 100, 6125-6128, (2009).

4. S. N. Dodic', S. D. Popov, J. M. Dodic', J. A. Rankovic', and Z. Z. Zavargo. Potential contribution of bioethanol fuel to the transport sector of vojvodina. renewable and sustainable energy reviews, 13, 21972200, (2009).

5. Lecture Material Food and Farm Management, Pengaruh substitusi tepung talas semir (colocasia esculenta (l) schott) dan penambahan lemak terhadap karakteristik organoleptik dan karakteristik lain cookies. http://bakulpangan. blogspot. com/2011/10/pengaruh-substitusi-tepungta-las-semir.html. 20 November 2011.

6. A. Setiasih, Pemafaatan talas (colocasiaesculenta) sebagai bahan baku pembuatan bioetanol, Universitas Diponegoro, Semarang, 1-12, 2011.

7. E. D. Retno, E. A. Kriswiyanti, dan Adrian Nur, Bioetanol fuel grade dari talas (colocasia esculenta), Ekuilibrium., 8(1), 16, (2009).

8. G. N. Huda, Bioetanol dari talas. lomba artikel, Institut Pertanian Bogor, 1-3, 2009.

9. D. Subashini, dkk., Ethanol production from sago waste using saccharomyces cerevisiae Vits-M1, School of biosciences and Technology, VIT University, India, 3(1) 42 51, (2011). 